\title{
SOURCE ROCK POTENTIAL OF LOWER-MIDDLE MIOCENE LACUSTRINE DEPOSITS: EXAMPLE OF THE KÜÇÜKKUYU FORMATION, NW TURKEY
}

\author{
AYŞE BOZCU* \\ Department of Geological Engineering, Engineering Faculty, Çanakkale Onsekiz \\ Mart University, Terzioğlu Campus, 17100 Çanakkale, Turkey
}

\begin{abstract}
The purpose of this study was to examine the geological, stratigraphic and organic geochemical features of the Küçükkuyu Formation outcropping on Biga Peninsula, NW Turkey. The Lower-Middle Miocene formation crops out around the Gulf of Edremit and near Bayramiç-Çan in the north of the Kazdağ Mountains. The unit is composed of shale, siltstone and sandstone intercalations. The shale is bituminous and represents a potential source rock in the region.

Shale samples from the formation were investigated. Rock-Eval pyrolysis, vitrinite reflectance (Ro \%), gas chromatography (GC), stable C isotope and total sulfur measurements were carried out. The shale is characterized by high total organic carbon (TOC) values (0.27 to $7.44 \mathrm{wt} \%$, average 1.69 $w t \%)$, indicating a good potential source rock. The kerogen types are II and III, indicating the shale to be gas and oil-prone. $T_{\max }$ values are between 352 and $453{ }^{\circ} \mathrm{C}$, the average value suggesting early catagenesis. The pristane/ phytane $(\mathrm{Pr} / \mathrm{Ph})$ values reveal suboxic and anoxic environments. Carbon preference index (CPI) and C isotope values reveal terrestrial OM.

Geological and stratigraphic evaluations and total sulfur (TS) figures indicate that the Küçükkuyu Formation was deposited in a suboxic-anoxic, freshwater environment (lacustrine), developing brackish water conditions from time to time.
\end{abstract}

Keywords: Küçükkuyu Formation, Miocene, bituminous shale, source rock, Biga Peninsula, NW Turkey.

\section{Introduction}

The study area is located north of the Gulf of Edremit, northwestern Anatolia (Fig. 1). The area of interest is southwest and north of the Kazdağ Massif on Biga Peninsula. The peninsula and surroundings are an important source region for industrial minerals, ore deposits and fossil fuel (especially

\footnotetext{
* Corresponding author: e- mail abozcu@comu.edu.tr
} 


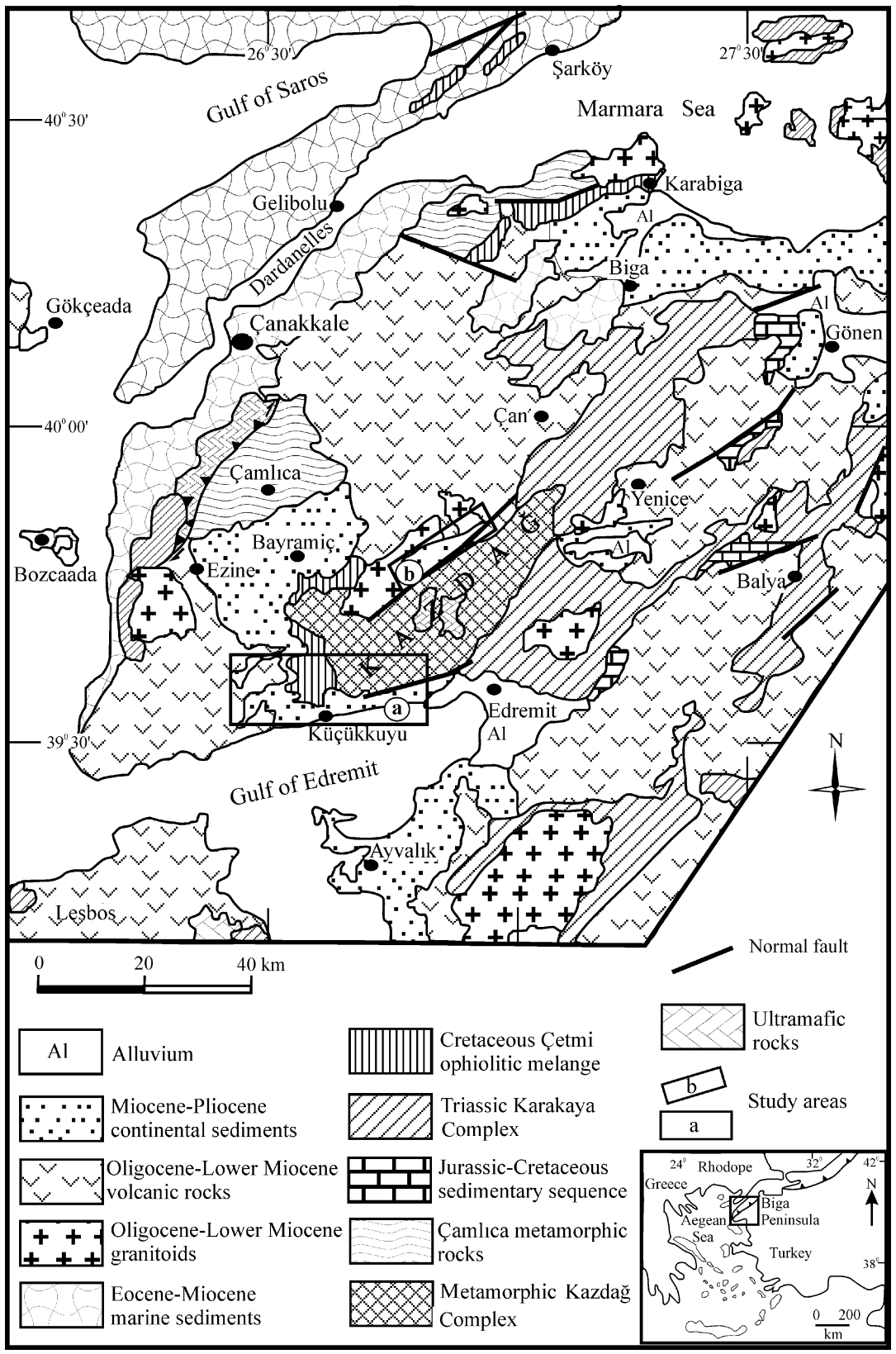

Fig. 1. Location map of Biga Peninsula and generalized geological map of the Gulf of Edremit and surroundings, northwestern Turkey, with the location of the studied areas (revised from [36, 37]).

lignite) in Turkey. The Küçükkuyu Formation is widely exposed on Biga Peninsula to the north and south of the Gulf of Edremit and represents a potential petroleum source rock in the region. In this study, stratigraphy and 
source rock characteristics of the formation outcropping on Biga Peninsula were investigated. The formation is composed of alternating shale, siltstone and sandstone and is Early-Middle Miocene age. The shale units are thinbedded, laminated and bituminous.

The hydrocarbon (HC) potential of the formation has been mentioned in previous studies [1-5]. Saka [1] refers to oil seepages in the Küçükkuyu Formation. Siyako et al. [2] indicate that the total organic carbon (TOC) values of the shale samples from the Küçükkuyu Formation ranged from 0.30 $1.17 \mathrm{wt} \%$ and volcanism in the region was negative in terms of organic matter maturity. According to Kesgin [3], TOC, $\mathrm{S}_{2}$, hydrogen index (HI), kerogen type, $\mathrm{T}_{\max }$ and vitrinite reflectance (Ro) values of the Küçükkuyu Formation show that the formation had source rock potential. Kerogen of the samples is Type III indicating gas prone.

According to Çiftçi et al. [4], elements occurring in active hydrocarbon systems are present in the area surrounding the Gulf of Edremit. The hydrocarbon potential of the northern Aegean Sea and the adjacent Turkish land area is of particular interest. The Prinos oil field of Greece in the northwestern part of the study area, gas fields in the Thrace Basin in the north and other hydrocarbon seeps in the region increase the potential of the region. In addition, the authors revealed TOC contents of the Küçükkuyu Formation were generally higher than $0.5 \%$ and $\mathrm{HI}$ values were up to $600 \mathrm{mg} \mathrm{HC} / \mathrm{g}$ TOC. Kerogen has been characterized as Type II or Type III.

A total of 275 outcrops and boreholes samples were analyzed by Çiftçi et al. [5] in the graben fill, all of western Anatolian graben basins, including the Edremit Graben. In this work, analysis values of all 275 samples are evaluated together. The total organic carbon (TOC) average was $2.34 \%$, and $80 \%$ of the samples had more than $0.5 \%$ TOC. Organic matter is generally amorphous and herbaceous, with coaly material. The hydrogen index and kerogen type show a wide range of distribution. Most of the kerogen samples are Type II, indicating a good oil-generative potential of the lacustrine shales of the region. Type III kerogen also exists and suggests that the organic matter is both oil and gas generative at maturation. The pyrolysis $T_{\max }$ values indicate that the outcrop samples are generally immature to mature for hydrocarbon generation whereas maturation is apparently increased in borehole samples, which are within the oil window.

Investigation of outcrop area and source rock characteristics of bituminous shale of western and northwestern Anatolia is important. Well drilling by the Turkish Petroleum Corporation (TPAO) in Gömeç in the southern part of the Gulf of Edremit, Edremit-1 well (1988) in the Gulf of Edremit, petroleum exploration drilling in Alaşehir (1998 and 2008), and Anafartalar-1 well drilling for natural gas in the Gulf of Saros (2008) have all produced gas. Bituminous shales of Biga Peninsula may be an important source rock for these hydrocarbons. 


\section{Geology and stratigraphy}

The basement of the Tertiary units on Biga Peninsula is comprised of tectono-stratigraphic units of different origin and age (Figs. 1, 2). These are:

(a)
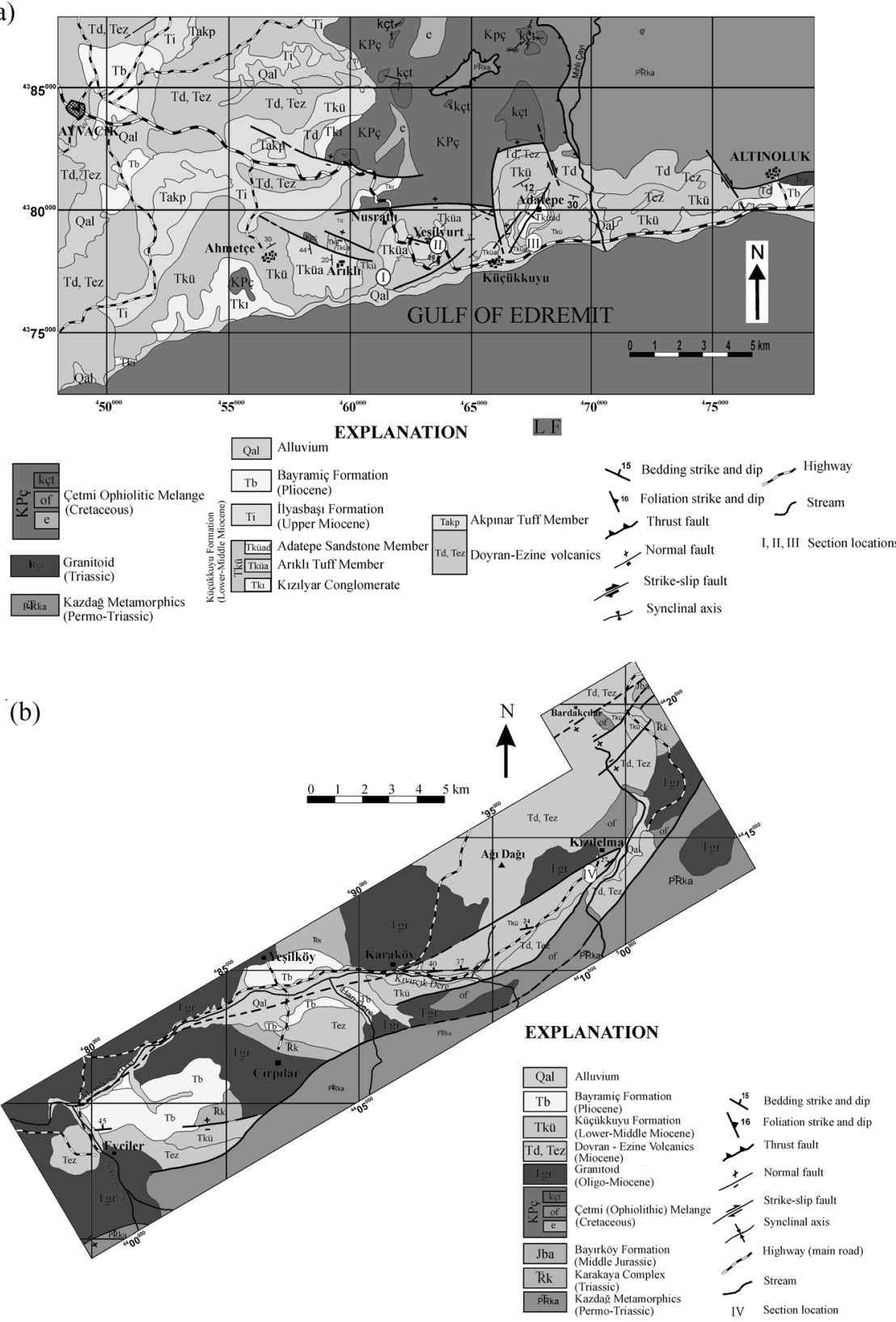

Fig. 2. Geological map showing outcrops of the Küçükkuyu Formation on Biga Peninsula and section locations (revised from [38]). 
(i) Kazdağ Group; (ii) Çamlıca Group (Çamlıca Metamorphics); (iii) Karakaya Complex; and (iv) Çetmi Ophiolitic Melange [6-10]. In the region, a very thick magmatic sequence $(>2500 \mathrm{~m})$ with various chemical compositions formed in the Eocene-Pliocene interval. The sequence has an interfingering contact with sedimentary rocks in places [11].

In the region, terrestrial deposits also developed with volcanic rocks in the Early-Middle Miocene. These are bituminous shale, claystone with intercalations of coal, siltstone, sandstone and tuff [1,2]. The Küçükkuyu Formation was deposited during this period in the northern part of the Gulf of Edremit, around Küçükkuyu and north of the Kazdağ Massif around Kızılelma on Biga Peninsula. The Lower-Middle Miocene Küçükkuyu Formation [1] starts with a conglomerate level, continues through sandstoneshale alternations, with observed tuff levels above, and ends with sandstone. The bituminous shale of the formation has source rock potential. The formation is divided into three members. The lowest is the Kizilyar Conglomerate, the tuffs are termed the Arıkl1 Tuff, and the upper sandstone forms the Adatepe Sandstone member. The formation is overlain unconformably by the İlyasbaşı Formation [1] (Fig. 3).

In the Upper Miocene-Pliocene, conglomerate, sandstone, shale, lignite and volcano-clastic layers were deposited and reflect fluvial and lacustrine environments. These sediments show lateral and vertical transition to shallow marine sandstone, conglomerate, shale, marl and oolitic limestones [2].

At the end of the Late Miocene in the region, volcanic activity was renewed and alkali basalts crop out along the young faults formed by extensional tectonics [12].

\subsection{The Küçükkuyu Formation}

Alternating bituminous shale and sandstone crop out extensively around the Gulf of Edremit. Three different members are distinguished on the basis of lithological and stratigraphic characteristics [1]. These are: the Kizılyar Conglomerate, the Arikl1 Tuff and the Adatepe Sandstone.

The Kizilyar Conglomerate consists of reddish, weakly cemented conglomerate and sandstone. The conglomerate is reddish, dark purplish-red and purple coloured, well rounded but poorly sorted and consists of andesite, chert, alkaline lava pebbles and coarse-grained sandstone layers around Kizilyar village (Fig. 4a). The age of the conglomerate is Early Miocene $[1,2,4]$. The depositional environment of the unit was braided-river and/or steeply dipping alluvial fan [13]. Lateral thickness change and geometry of the unit reflect sedimentation of fan sediments in a section near Kizilyar village. Sedimentation conditions and lithological properties of the conglomerate indicate that the formation formed in a fault-controlled basin.

Volcanics (Doyran Volcanics) and volcaniclastics with terrestrial conglomerates (Kizilyar Conglomerate) occur in the lower part of the formation. Above this, the main facies consist of shale, siltstone and sandstone intercalations (Fig. 4b). The shale is greenish-brownish grey, dark grey and black 


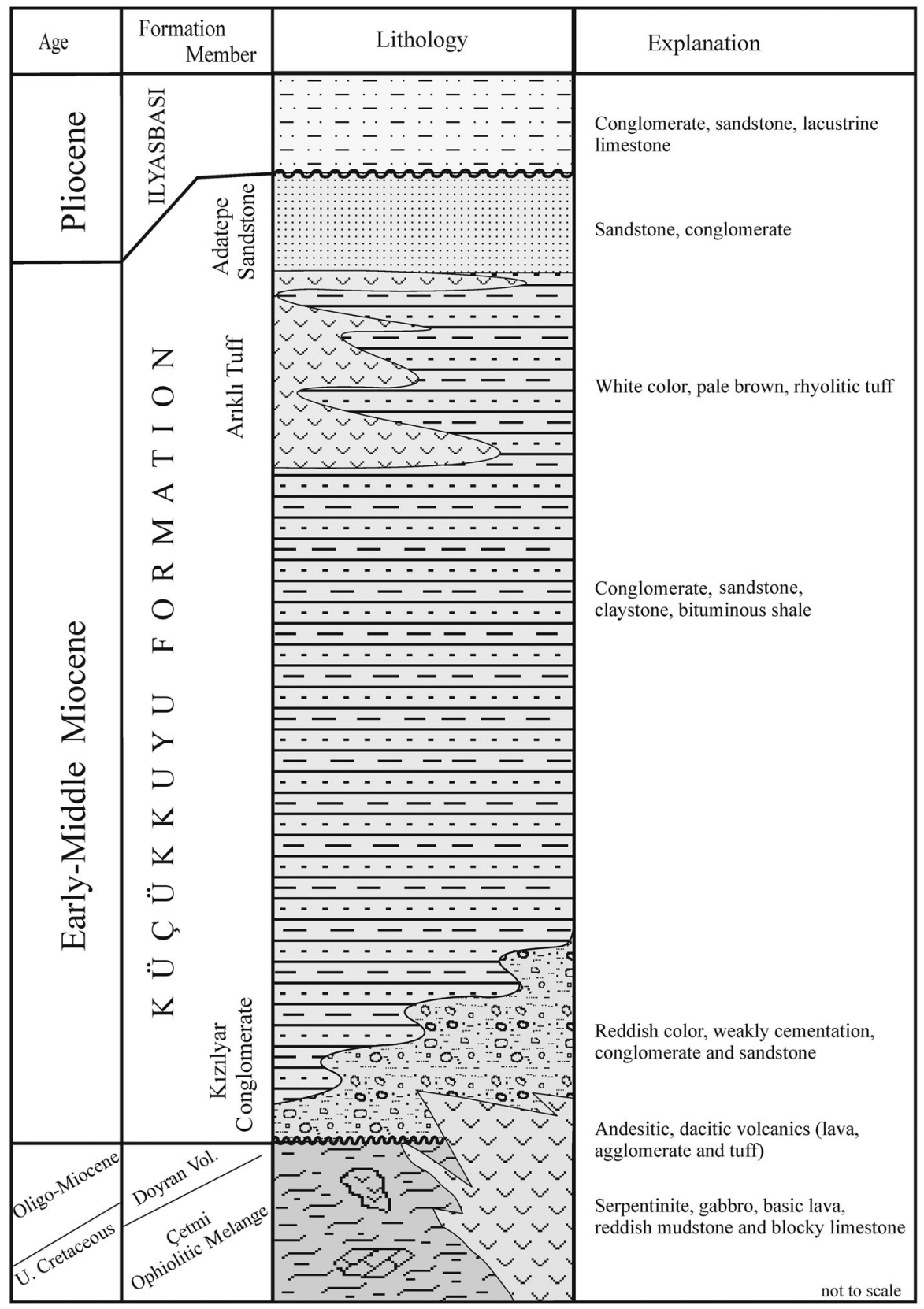

Fig. 3. Stratigraphic column of the Küçükkuyu Formation. (Abbreviations used: U. Upper; Vol. - volcanics). 

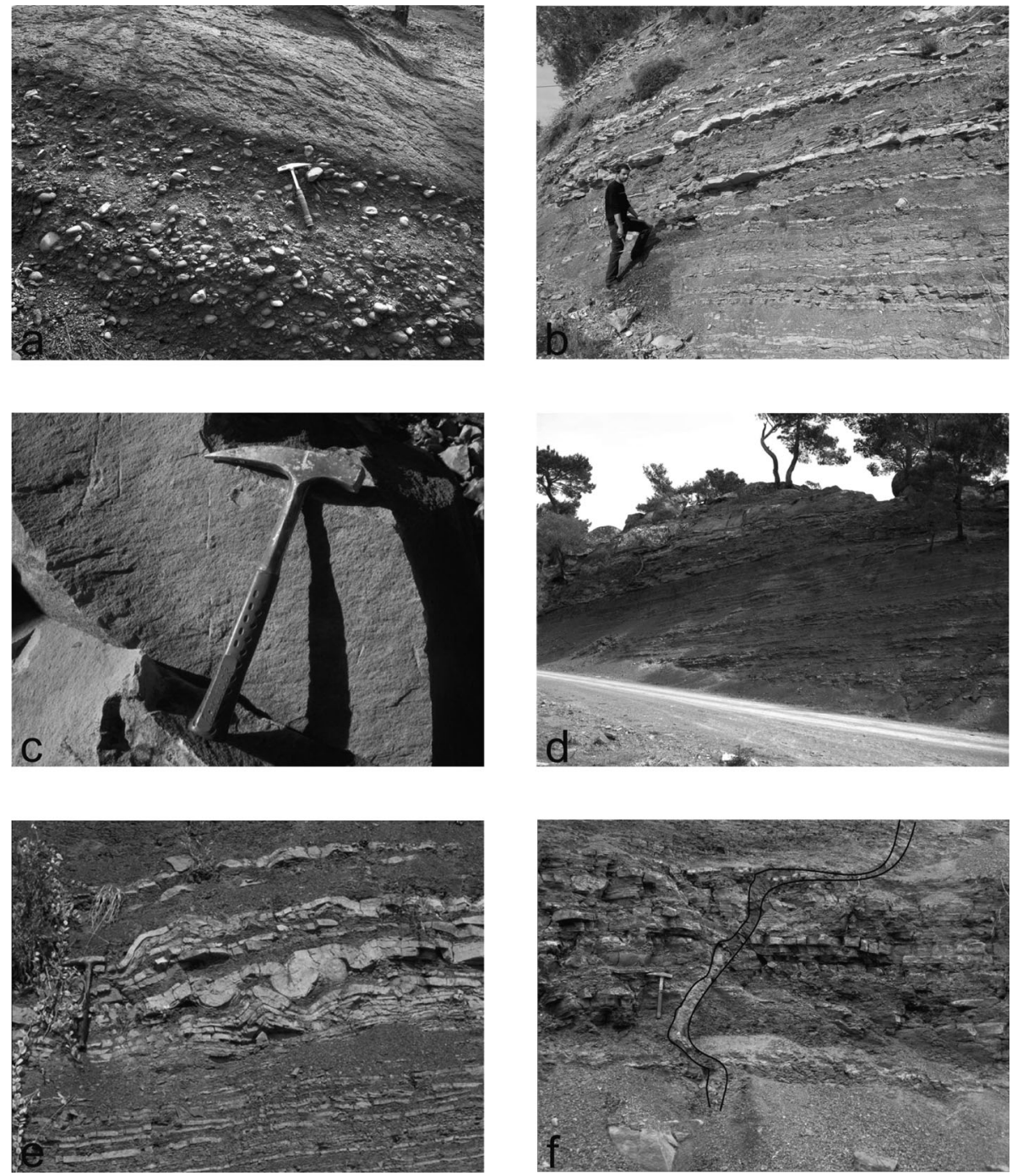

Fig. 4. Field photographs of the Küçükkuyu Formation: a - close-up view of the Kizilyar Conglomerate, $\mathrm{b}$ - bituminous shale-sandstone alternation, c - Arıklı Tuff member, $\mathrm{d}$ - Adatepe Sandstone member, e - slump structure, $\mathrm{f}-$ mud dyke.

in organic-rich levels and shows thin bedding, laminations, spheroidal weathering and paper shale features. Slump structures, synsedimentary faults and folds are frequently observed in the unit. Tuff and sandstone content (Arıklı Tuff and Adatepe Sandstone members) increases through the middleupper parts of the formation.

The Arıkl Tuff is white-beige in colour on a fresh surface and yellowbrownish on weathered surfaces. It is thick-bedded, massive and quite hard in unweathered areas (Fig. 4c) The tuff also contains thick-medium bedded tuffite levels. In the thin section it consists of fine grained components and 
has vitric tuff characteristics. Quartz-plagioclase minerals and ferrous alteration are observed.

The Adatepe Sandstone occurs in the upper level of the formation (Fig. 4d). It crops out in a restricted area in the synclinal structure to the north of Küçükkuyu near Adatepe village. The unit starts with sandstoneshale alternation at lower levels, passing up to sandstone with pebbles. The dominant lithology is tuffite and carbonate-cemented sandstone.

Coal plant fragments, thin coal levels and pyrite crystals are observed in the formation. Synsedimentary and syntectonic structures are also widely observed. Synsedimentary structures include planar parallel stratification, lamination, grading, spheroidal sandstone-siltstone nodules, ripple marks, slump structures (Fig. 4e) and mud dykes (Fig. 4f).

The stratigraphy of the formation is shown in four detailed lithological columns established from key areas (Fig. 2/ I, II, III, IV section locations). These are the Arıklı section (Fig. 2/ I, Fig. 5a), the Yeşilyurt section (Fig. 2/ II, Fig. 5b), the Adatepe section (Fig.2/ III, Fig. 5c) and the Kizilelma section (Fig. 2/ IV). The Arikl section of the formation along the road south of Arıklı village to Nusratlı village represents the lower part of the formation. The formation starts with polygenic conglomerate and ends with tuffs (Arıkl1 Tuff). The sequence in the area consists of alternating claystone, siltstone and sandstone. The sandstone with pebbles reach $2 \mathrm{~m}$ in thickness; sandstone, limestone, coarse sandstone-conglomerate reaching $1 \mathrm{~m}$ in thickness are present in the section. Chert nodules in the bottom levels, and synsedimentary mud dykes and slumps in the upper levels are observed.

The Yeşilyurt section represents the middle part of the formation. It starts with alternating sandstone-shale at the entrance of Yeşilyurt village. Sandstone interbeds reach $40-50 \mathrm{~cm}$ in thickness, shale with carbonated sandstone nodules is observed, continuing to sandstone-shale alternations, and ending with carbonated claystone, siltstone and sandstone. Shale in the section is dark grey-black coloured.

The Adatepe section measured along the Küçükkuyu-Adatepe road represents the upper part of the formation. The main rock type is alternating sandstone-shale. The upper part (around Adatepe village) of the section consists of coarse-grained sandstone and conglomeratic sandstone (Adatepe Sandstone). Claystone reaching $10 \mathrm{~m}$ in thickness and sandstone beds reaching $60-70 \mathrm{~cm}$ in thickness are observed along the section.

The Kizilelma section, in the northern part of the study area, starts with a loosely cemented conglomerate layer with volcanic blocks above the volcanics and continues through sandstone-conglomerate and sandstoneshale layers. Shale is black, thinly foliated and shows paper shale features. Sandstone-shale alternation is dominant along the section. Limestone $(20 \mathrm{~cm}$ thick), channel-filling conglomerate (70 cm thick), and sandstone-conglomerate $5 \mathrm{~m}$ in thickness are observed in the section. The measured section thickness in this area is $400 \mathrm{~m}$. 
The total thickness of the Küçükkuyu Formation was measured average $900 \mathrm{~m}$ in sections around Küçükkuyu by Saka [1]. It is stated that in the Gulf of Edremit the formation is more than $900 \mathrm{~m}$ thick. In this study the measured thickness of the formation is about $400 \mathrm{~m}$.

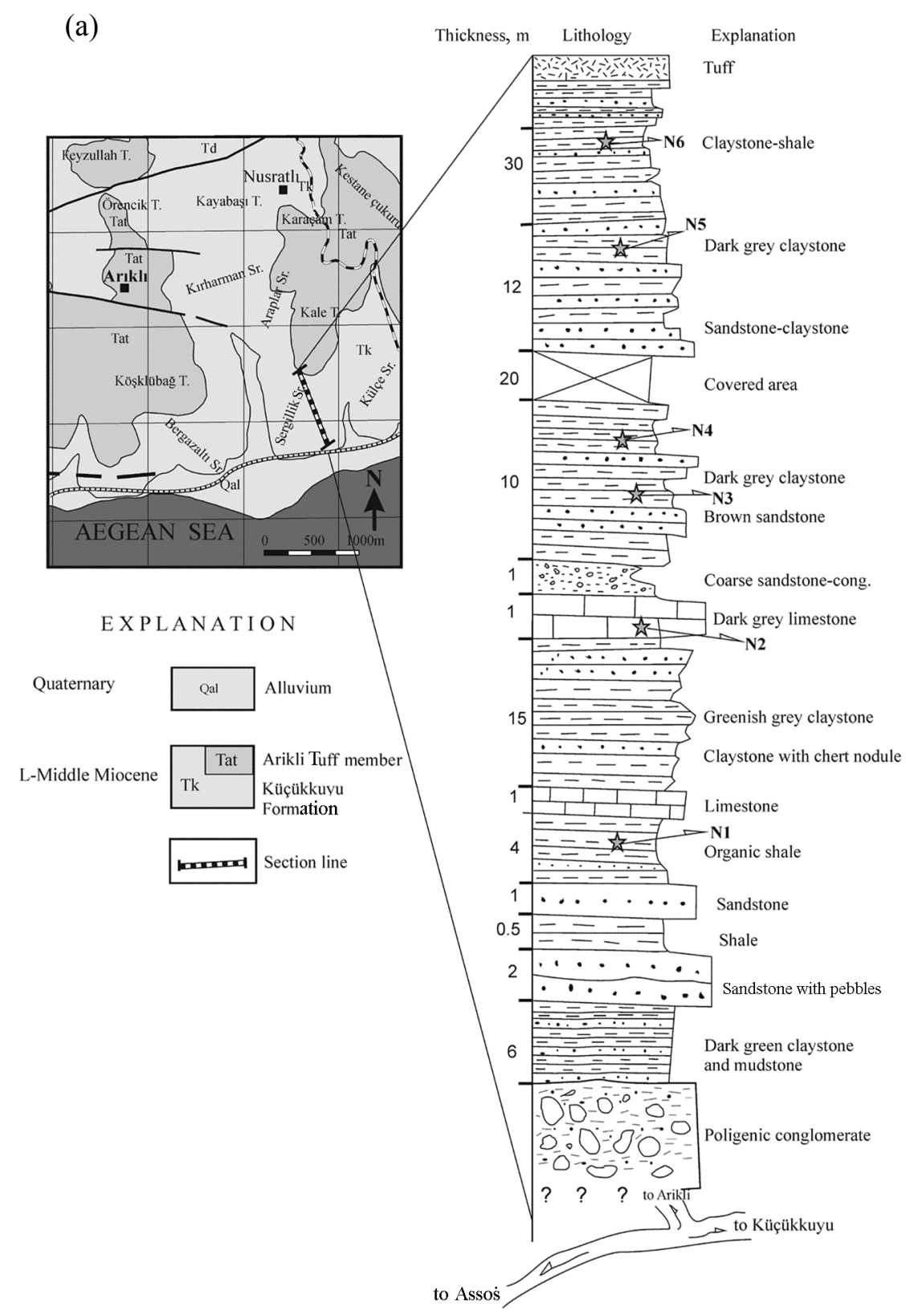

Fig. 5. Sections of the Küçükkuyu Formation: (a) Arıklı section (I in Fig. 2a). (Abbreviations used: L-Middle - Lower-Middle, Form. - Formation, cong. conglomerate.) 


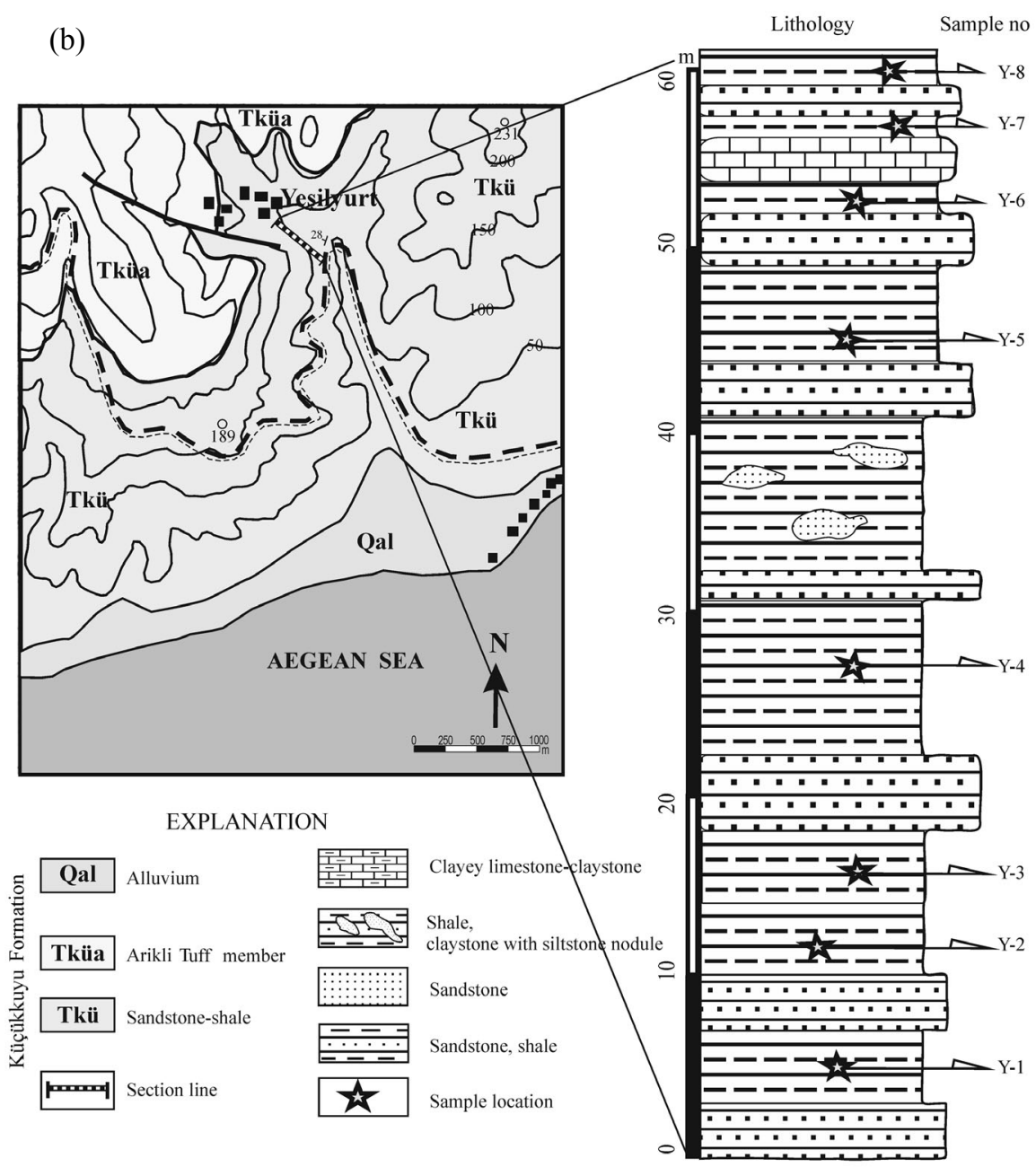

Fig. 5. Sections of the Küçükkuyu Formation: (b) Yeşilyurt section (II in Fig. 2a).

The age of the formation is Early Miocene. The first age data came from [14], determining it to be Miocene according to palynomorph associations from bituminous shale. According to the palynomorph group determined by Kesgin [3], the age of the formation is Early-Middle Miocene. Beccaletto [13] dated a biotite grain sampled from a detrital tuffite of the upper member (equivalent to Adatepe Sandstone) of the formation using the ${ }^{40} \mathrm{Ar} /{ }^{39} \mathrm{Ar}$ method. Late Eocene age (Priabonian) established by this method is interpreted as the age of volcanism that provided the source rock for detritus at the time of deposition of the upper member [13]. Çiftçi et al. [4] determined the age of the formation to be Early-Middle Miocene according to characteristic spores accepted as the index taxon for the Early-Middle Miocene. 


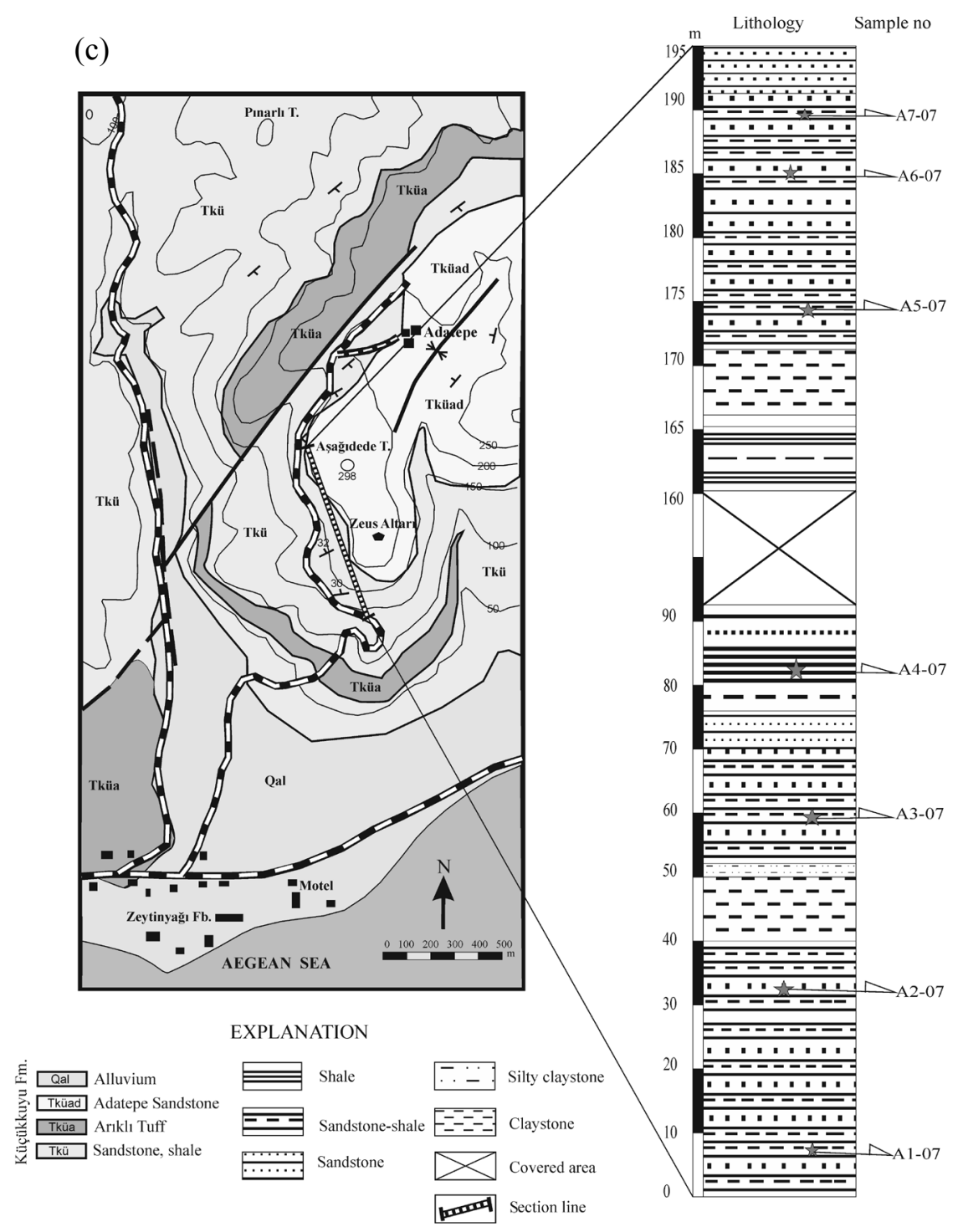

Fig. 5. Sections of the Küçükkuyu Formation: (c) Adatepe section (III in Fig. 2a). (Abbreviation used: Fm. - Formation.)

\section{Material and methods}

Twenty-eight outcrop samples of potential source rock were collected from the Küçükkuyu Formation. Rock-Eval pyrolysis, gas chromatography (GC), stable carbon isotope and total sulfur analyses were carried out. Vitrinite reflectance studies were also performed. The analyses were performed at the Research Group Laboratories of Turkish Petroleum Corp. (TPAO). Pyrolysis was carried out using a RockEval-6 device, IFP 160000 (Institut Français du 
Pétrole) standard Table 1. Five samples for GC were extracted using dichloromethane in a Soxhlet apparatus. Samples prepared from the extract were analysed according to the ASTM D 5307-97 (Reapproved 2002) ${ }^{\mathrm{e} 1}$ method. Carbon isotope analysis (5 samples) used a GV Instruments Isoprime gas chromatography-combustion-isotope ratio mass spectrometry (GC-C-IRMS) apparatus. The results are reported accordingly as $\delta^{13} \mathrm{C} \%$ vs. VPDB, calibrated according to international standards in which standard deviation can be accepted at $95 \%$ confidence interval (calibrated according to NSG 1 and NSG 2 gas standards).

Table 1. Rock-Eval pyrolysis results for Küçükkuyu Formation samples

\begin{tabular}{|c|c|c|c|c|c|c|c|c|c|c|c|}
\hline Sample & $\mathrm{TOC}^{\mathrm{a}}$ & $\mathrm{S}_{1}{ }^{\mathrm{b}}$ & $\mathrm{S}_{2}{ }^{\mathrm{c}}$ & $\mathrm{S}_{3}{ }^{\mathrm{d}}$ & $\mathrm{T}_{\max }{ }^{\mathrm{e}}$ & $\mathrm{HI}^{\mathrm{f}}$ & $\mathrm{OI}^{\mathrm{g}}$ & $\mathrm{PI}^{\mathrm{h}}$ & $\mathrm{RC}^{\mathrm{i}}$ & $\mathrm{PC}, \%^{\mathrm{j}}$ & $\begin{array}{c}\text { MINC, } \\
\% \mathrm{k}\end{array}$ \\
\hline Y-1 & 4.18 & 0.26 & 11.8 & 1.89 & 438 & 282 & 45 & 0.02 & 3.1 & 1.08 & 0.34 \\
\hline Y-2 & 2.08 & 0.42 & 11.4 & 1.39 & 439 & 548 & 67 & 0.04 & 1.04 & 1.04 & 0.14 \\
\hline$Y-4$ & 1.7 & 0.2 & 9.6 & 1.22 & 440 & 565 & 72 & 0.02 & 0.84 & 0.86 & 0.46 \\
\hline Y-8 & 1.55 & 0.19 & 6.47 & 1.08 & 423 & 417 & 70 & 0.03 & 0.95 & 0.6 & 0.12 \\
\hline U-1 & 7.44 & 0.67 & 67 & 1.12 & 443 & 900 & 15 & 0.01 & 1.68 & 5.76 & 0.42 \\
\hline U2-07 & 57.77 & 1.79 & 58.4 & 19.68 & 442 & 101 & 34 & 0.03 & 51.52 & 6.25 & 1.5 \\
\hline A2-07 & 0.93 & 0.23 & 1.63 & 1.03 & 445 & 175 & 111 & 0.12 & 0.74 & 0.19 & 2.73 \\
\hline A4-07 & 1.54 & 1.07 & 2.74 & 0.73 & 443 & 178 & 47 & 0.26 & 1.2 & 0.34 & 0.19 \\
\hline N-6 & 1.04 & 0.01 & 1.57 & 0.93 & 440 & 151 & 89 & 0.01 & 0.87 & 0.17 & 0.06 \\
\hline B-1 & 3.91 & 0.28 & 15.8 & 2.21 & 431 & 404 & 57 & 0.02 & 2.48 & 1.43 & 0.26 \\
\hline B-2 & 0.27 & 0.02 & 0.11 & 0.58 & 414 & 41 & 215 & 0.12 & 0.24 & 0.03 & 0.52 \\
\hline Kü-07 & 0.98 & 0.82 & 4.98 & 0.88 & 438 & 508 & 90 & 0.14 & 0.47 & 0.51 & 2.44 \\
\hline Kü-2 & 2.43 & 0.17 & 5.36 & 1.47 & 440 & 221 & 60 & 0.03 & 1.91 & 0.52 & 0.19 \\
\hline Kü-5 & 6.1 & 0.24 & 33.8 & 1.83 & 438 & 554 & 30 & 0.01 & 3.18 & 2.92 & 0.14 \\
\hline Kü-6 & 0.56 & 0.01 & 0.21 & 0.74 & 450 & 38 & 132 & 0.06 & 0.51 & 0.05 & 0.58 \\
\hline Kü-10 & 0.97 & 0.12 & 0.52 & 0.43 & 453 & 54 & 44 & 0.19 & 0.9 & 0.07 & 0.53 \\
\hline Kü-11 & 1.34 & 0.16 & 1.14 & 1.00 & 448 & 85 & 75 & 0.12 & 1.2 & 0.14 & 0.85 \\
\hline K3-07 & 0.5 & 0.02 & 0 & 0.45 & 352 & 0 & 90 & 1 & 0.48 & 0.02 & 0.11 \\
\hline K1-08 & 0.83 & 0.02 & 0.01 & 0.25 & - & 1 & 30 & 0.76 & 0.82 & 0.01 & 1 \\
\hline K2-08 & 1.56 & 0.03 & 0.03 & 0.87 & - & 2 & 56 & 0.45 & 1.53 & 0.03 & 0.25 \\
\hline K5-08 & 0.98 & 0.01 & 0.03 & 1.11 & - & 3 & 113 & 0.28 & 0.94 & 0.04 & 0.08 \\
\hline K11-08 & 0.75 & 0.01 & 0.01 & 0.82 & - & 1 & 109 & 0.63 & 0.72 & 0.03 & 0.1 \\
\hline K12-08 & 0.87 & 0.02 & 0.04 & 0.78 & - & 5 & 90 & 0.36 & 0.84 & 0.03 & 0.35 \\
\hline K14-08 & 0.8 & 0.01 & 0.02 & 1.17 & - & 2 & 146 & 0.36 & 0.76 & 0.04 & 0.38 \\
\hline O-07 & 0.28 & 0.01 & 0 & 0.43 & 411 & 0 & 154 & 1 & 0.26 & 0.02 & 2.9 \\
\hline O1-08 & 0.48 & 0.02 & 0.01 & 0.41 & - & 2 & 85 & 0.58 & 0.47 & 0.01 & 1.88 \\
\hline $\mathrm{O} 2-08$ & 1.17 & 0.01 & 0.01 & 1.35 & - & 1 & 115 & 0.56 & 1.13 & 0.04 & 0.17 \\
\hline Ç1-08 & 0.5 & 0.01 & 0 & 0.76 & - & 0 & 152 & 0.56 & 0.48 & 0.02 & 4.82 \\
\hline $\begin{array}{l}\mathrm{a}-\text { total or } \\
\mathrm{b}-\mathrm{mg} \mathrm{HC} \\
\mathrm{c}-\mathrm{mg} \mathrm{HC} \\
\mathrm{d}-\mathrm{mg} \mathrm{CO} \\
\mathrm{e}-\text { temp ( } \\
{ }^{\mathrm{c}}-\text { hydroge }\end{array}$ & $\begin{array}{l}\text { nic car } \\
\text { rock; } \\
\text { rock; } \\
\text { rock; } \\
\text { of ma } \\
\text { index, }\end{array}$ & on, wt & TOC; & & & \multicolumn{6}{|c|}{$\begin{array}{l}{ }^{\mathrm{h}} \text { - production index, } \mathrm{S} 1 / \mathrm{S} 1+\mathrm{S} 2 ; \\
\mathrm{i}-\text { residual carbon, } \\
\text { TOC }-[0.83(\mathrm{~S} 1+\mathrm{S} 2) / 10] ; \\
\mathrm{j}-\text { pyrolyzed carbon, wt } \% \text {; } \\
{ }^{\mathrm{k}} \text { - mineral carbon, wt } \%\end{array}$} \\
\hline
\end{tabular}




\section{Source rock geochemistry}

\subsection{Geochemical analysis}

The amount of organic matter $(\mathrm{OM})$ can easily be estimated from an organic carbon analysis for total organic carbon (TOC). The quality and maturity of $\mathrm{OM}$ can be evaluated using different chemical and optical techniques. Pyrolysis is probably the best routine tool for determining OM type and maturity at the same time [15]. Twenty-eight shale samples were selected to evaluate the hydrocarbon generation potential. The results for these outcrop samples are shown in Table 1. Most of the samples (from Y-1 to Kü-11) are from around Küçükkuyu (Fig. 2a), samples from K3-07 to Ç1-08 are from around Kizilelma (Fig. 2b).

\subsubsection{Amount of OM}

The samples were analyzed for TOC content (Table 1). TOC ranges from 0.27 to $7.44 \mathrm{wt} \%$ (except for one sample, $57.77 \mathrm{wt} \%$ ). The values are generally greater than the $0.5 \mathrm{wt} \%$ threshold required for clastic source rocks to generate oil [16]. Half of the 28 samples have TOC $>1 \mathrm{wt} \%$. Average values are $1.69 \mathrm{wt} \%$ (57.77 $\mathrm{wt} \%$ outlier removed). So, according to these values the Küçükkuyu Formation is a good source rock. The TOC content of Küçükkuyu samples reaches on average $2.31 \mathrm{wt} \%$, while the Kızılelma samples have an average TOC value of $0.79 \mathrm{wt} \%$. The Küçükkuyu samples are better source rock than the Kizllelma samples. In addition, the Küçükkuyu samples representing the middle level of the formation (especially Y-1, Y-2, Y-4, Y-8) have higher TOC and HI values.

HI values for the Küçükkuyu and Kızılelma samples are different. The HI values of Küçükkuyu samples range from 38 to $900 \mathrm{mg} \mathrm{HC} / \mathrm{g}$ TOC, whereas those of Kizılelma samples are very low, being between 0 and $5 \mathrm{mg} \mathrm{HC/g}$ TOC (Table 1).

\subsubsection{Kerogen type}

Kerogen can provide essential information on topics such as past environments, climates and biota [17].

Sedimentary rocks contain three types of kerogen. These are: Type I (algal kerogen), Type II (liptinitic kerogen) and Type III (humic kerogen). According to pyrolysis analysis the types can be distinguished on two different plots: hydrogen index (HI) vs. oxygen index (OI) and hydrogen index (HI) vs. $\mathrm{T}_{\max }$. Plotting values of $\mathrm{HI}$ against those of OI on a van Krevelen-type diagram (Fig. 6) reveals a predominance of Type II and III kerogens. HI values in the range of 0 to $200 \mathrm{mg} \mathrm{HC} / \mathrm{g}$ TOC represent humic (terrestrial), 200 to $600 \mathrm{mg} \mathrm{HC} / \mathrm{g}$ TOC mixed (liptinitic) and, 600 to $1000 \mathrm{mg} \mathrm{HC} / \mathrm{g}$ TOC sapropelic (algal) OM. Most samples (19 of 28) reveal humic (terrestrial) OM and 8 mixed (Type II-III) OM. Type II-III kerogen is oil and gas-prone, so the formation in Biga Peninsula has a potential for 
producing oil and gas. It is noted that HI values of all of the Kizılelma samples range from 0 to $5 \mathrm{mg} \mathrm{HC/g}$ TOC, indicating Type IV kerogen $(\mathrm{HI}<50$, inertinitic or recycled kerogen) according to Peter and Cassa [18].

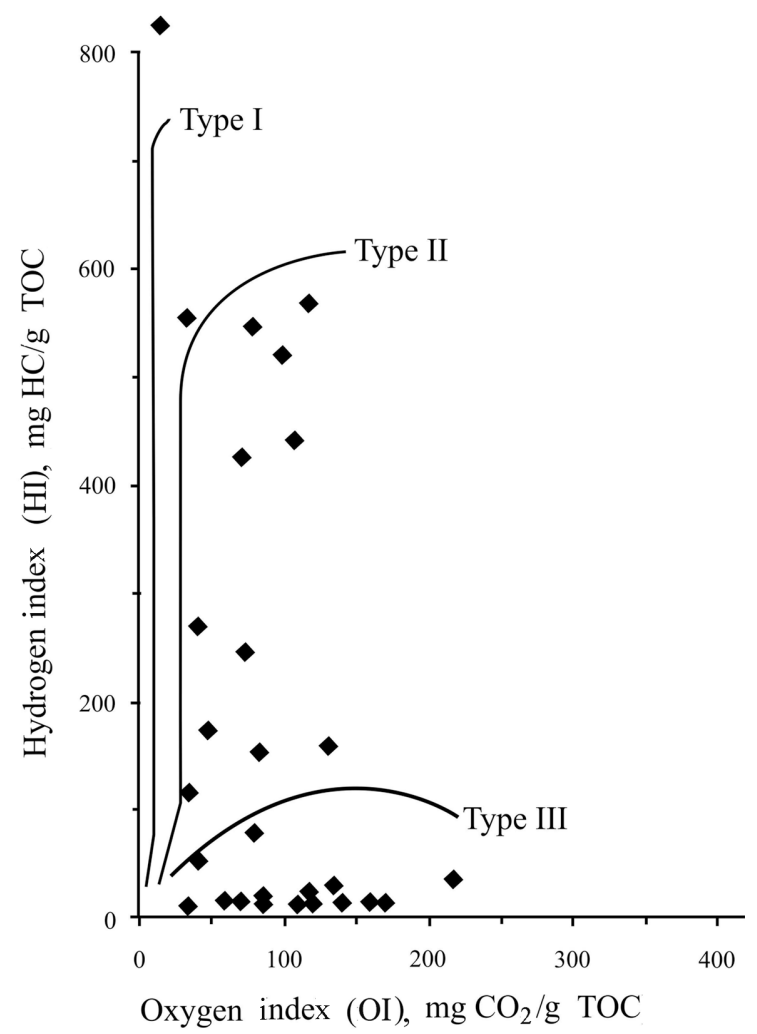

Fig. 6. HI vs. OI distribution [39] to indicate the type of organic matter of the analyzed samples from the Küçükkuyu Formation.

\subsubsection{OM maturity}

The level of maturity can be evaluated from vitrinite reflectance data (Ro, \%), Rock-Eval pyrolysis $\left(\mathrm{T}_{\max }\right)$ and biomarker parameters [19, 20]. Ro data and $\mathrm{T}_{\max }$ values are given in Tables 2 and 1, respectively. Ro values $<0.5 \%$ indicate immature OM and values between 0.5 and $2 \%$ mature (main zone of oil formation) $\mathrm{OM}$, values in the range of $2-4 \%$ over mature $\mathrm{OM}$ [19]. For the samples measured the values (except for one) show beginning maturation (Table 2). Based on $\mathrm{T}_{\max }$ values, 13 samples are early mature (catagenetic stage, $438-453{ }^{\circ} \mathrm{C}$ ) and 5 are immature (diagenetic stage, 352$431{ }^{\circ} \mathrm{C}$ ). Almost all of these samples are from the Küçükkuyu area.

The production index, $\mathrm{PI}=\mathrm{S} 1 /(\mathrm{S} 1+\mathrm{S} 2)$, can also be used to determine maturity $[16,18]$. Values of PI, for most of the Küçükkuyu samples, are less than 0.1 , averaging 0.07 (Table 1), indicating immature. However, the PI of 
most of the Kizilelma samples is greater than 0.4 , averaging 0.59 (Table 1), indicating over mature (18). PI data therefore show that the Küçükkuyu Formation is not sufficiently mature to generate oil and gas in the Küçükkuyu area but is over mature in the Kızılelma area.

Table 2. Vitrinite reflectance (Ro\%) analyses results for the Küçükkuyu Formation

\begin{tabular}{|l|c|}
\hline \multicolumn{1}{|c|}{ Sample } & Ro, $\%$ \\
\hline A2-07 & 0.55 \\
Kü-5 & 0.50 \\
Kü-10 & 0.88 \\
U2-07 & 0.51 \\
K2-08 & 1.44 \\
\hline
\end{tabular}

\subsubsection{Hydrocarbon potential}

Potential Yield $(\mathrm{PY}=\mathrm{S} 1+\mathrm{S} 2)$ or Genetic Potential is evaluated using the pyrolysis data to determine the hydrocarbon generation potential. PY values of the majority of Küçükkuyu samples suggest good source rock potential. S1 and S2 values of Kizilelma samples are close to zero or zero. Therefore there is no hydrocarbon potential of the samples in this area. In addition, all samples in this area are overmature and their HI values are very low.

\subsection{Gas chromatography}

According to Didyk et al. [21], low $\mathrm{Pr} / \mathrm{Ph}$ values $(<1)$ indicate anoxic conditions, higher values $(>1)$ oxic conditions and, values between 1.0 and 3.0 point to dysoxic environments. The values are affected by maturation [16].

$\mathrm{Pr} / \mathrm{Ph}$ values $(0.24-1.42)$ for five samples are shown in Table 3, indicating that two were deposited in an anoxic environment, and three in a suboxic environment. According to carbon preference index (CPI) for $n$-alkanes, values $>1$ indicate terrestrial $\mathrm{OM}$, values around 1 mature oil and values $<1$ early mature oil. The values for the samples are between 0.70 and 1.67. The $\mathrm{OM}$ is mainly terrestrial and the maturity of the samples ranges from early mature to mature.

Table 3. Gas chromatography results for Küçükkuyu Formation samples

\begin{tabular}{|l|c|c|c|c|}
\hline \multicolumn{1}{|c|}{ Sample } & $\mathrm{Pr} / \mathrm{Ph}$ & $\mathrm{Pr} / \mathrm{n}-\mathrm{C}_{17}$ & $\mathrm{Ph} / \mathrm{n}-\mathrm{C}_{18}$ & $\mathrm{CPI}_{25-33}$ \\
\hline Y-2 & 1.13 & 1.70 & 1.39 & 1.67 \\
Kü-11 & 1.42 & 0.25 & 0.16 & 1.24 \\
$\mathrm{~B}-1$ & 0.24 & 2.55 & 11.94 & 1.04 \\
K1-08 & 1.23 & 0.76 & 0.51 & 0.70 \\
K11-08 & 0.24 & 0.19 & 0.37 & 1.20 \\
Average & 0.85 & 1.09 & 2.87 & 1.17 \\
\hline
\end{tabular}




\subsection{Stable $C$ isotope}

The stable carbon isotope compositions are shown in Table 4. Many terrestrial plants have $\delta^{13} \mathrm{C}$ values in the range of -24 to $-34 \%$. Meyers [22] points out that marine OM typically has values between -20 and $-22 \%$. Values for the samples investigated in this work range from -25.37 to $29.26 \%$. According to these, the OM is not of marine origin.

Table 4. Stable carbon isotope values for Küçükkuyu Formation samples

\begin{tabular}{|l|c|}
\hline \multicolumn{1}{|c|}{ Sample } & $\delta^{13} \mathrm{C}$ \\
\hline Y-2 & -29.26 \\
Kü-11 & -27.39 \\
B-1 & -26.15 \\
K1-08 & -27.95 \\
K11-08 & -25.37 \\
\hline
\end{tabular}

\section{Total sulfur}

The relationship between total sulfur (TS, \%) and TOC (\%) is used to distinguish oxic-anoxic, and marine-freshwater depositional environments $[23,24]$. TS analysis was performed on 15 samples. Results for TOC and TS are shown in Table 5, TOC vs. TS in Figure 7. The C/S (TOC/TS) ratio is used to distinguish freshwater environment from marine environment, marine samples having low (0.5-5) values, while samples deposited in fresh water have high $(>10)$ values [25]. The values for the samples in this work are generally $>10$, indicating that they were deposited in a lacustrine freshwater environment.

Table 5. TOC, TS and TOC/TS values of the Küçükkuyu Formation

\begin{tabular}{|l|c|c|c|}
\hline \multicolumn{1}{|c|}{ Sample } & TOC, $\%$ & TS, $\%$ & TOC/TS \\
\hline Y-2 & 2.08 & 0.041 & 50.73 \\
Y-4 & 1.7 & 0.12 & 14.16 \\
Y-8 & 1.55 & 0.077 & 20.12 \\
U-1 & 7.44 & 0.95 & 7.83 \\
A4-07 & 1.54 & 0.012 & 128.33 \\
N-6 & 1.04 & 0.026 & 40 \\
B-1 & 3.91 & 0.062 & 63.06 \\
Kü-07 & 0.98 & 0.038 & 25.78 \\
Kü-2 & 2.43 & 0.029 & 83.79 \\
Kü-5 & 6.1 & 0.63 & 9.68 \\
Kü-10 & 0.97 & 0.012 & 80.83 \\
K3-07 & 0.5 & 0.019 & 26.31 \\
K2-08 & 1.56 & 0.034 & 45.88 \\
K5-08 & 0.98 & 0.011 & 89.09 \\
O2-08 & 1.17 & 0.026 & 45 \\
\hline
\end{tabular}




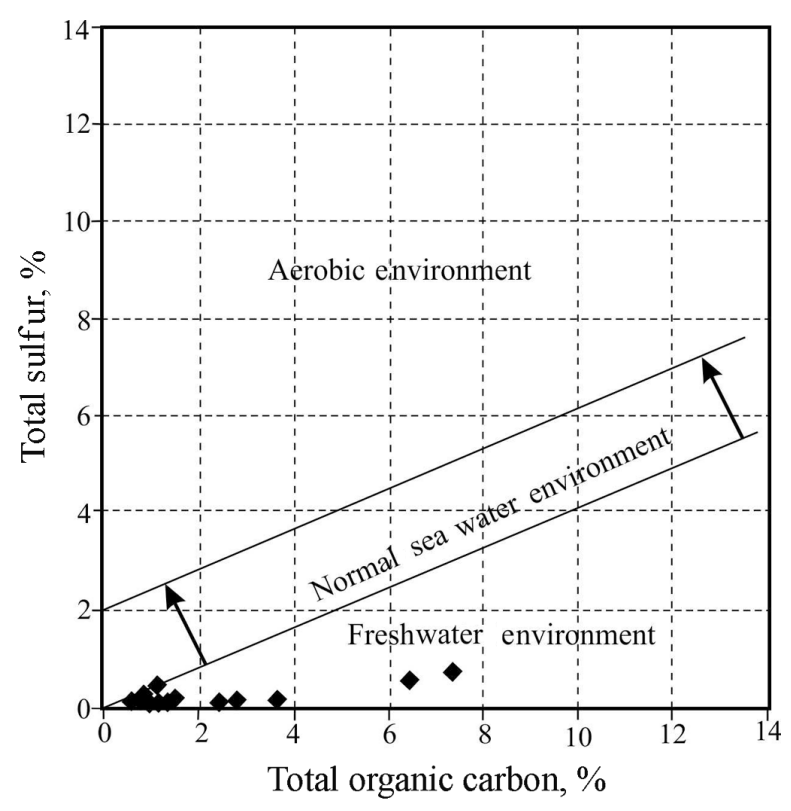

Fig. 7. TOC (\%) vs. TS (\%) diagram [24].

\section{Discussion and Conclusions}

The Küçükkuyu Formation crops out around the Gulf of Edremit in northwest Turkey. The region is shaped by a combination of the Aegean extensional tectonic regime and the strike slip faulting related to the North Anatolian fault system [26]. The Thrace Basin is situated north of, the Prinos Basin northwest of and the Aegean Graben Basin south of the Gulf of Edremit. The geology and hydrocarbon potential of the formation are different from those of Thrace and Prinos basins. The Eocene-Oligocene sequence is the main element in the hydrocarbon system in the Thrace Basin, containing economic oil and gas. The Prinos Basin has the only production field in Greece, where oil and gas have been produced for more than twenty years [27]. The Prinos Basin has a thick Miocene sedimentary sequence; marine claystone of Middle to Upper Miocene age and Messinian claystone deposited under highly reducing conditions interrupted by hypersaline episodes are considered to be the source of the oil in the basin [27]. Tertiary units in the Gulf of Edremit and surrounding areas are important for the hydrocarbon system. The Lower-Middle Miocene Küçükkuyu Formation is widely exposed on the northern Biga Peninsula and the southern part of the Gulf of Edremit and represents a potential source rock in the region. In the northern part of the gulf, on Biga Peninsula, the formation crops out along northern, western and southern parts of the Kazdağ Massif and was deposited in a fault controlled lacustrine environment before exhumation of the massif. 
It is known that lacustrine sediments with source rock potential exist in western Anatolia, including the Küçükkuyu Formation. The source rock potential is associated with the following Lower(?)-Middle Miocene deposits [5]: the Küçükkuyu Formation in the Edremit Graben [4], the Alaşehir Formation in the Gediz Graben [28], the Soma Formation in the Bakırçay Graben [29], the Soğukçam Formation in the Büyük Menderes Graben [30] and the Söke Formation in the Söke Graben [31]. The Neogene sedimentary sequences of these basins are mainly composed of continental clastics with minor carbonates. The thicknesses of the sequences are different, but the main depocenter thicknesses of the Edremit, Gediz, Büyük Menderes and Denizli grabens are in the range of 1500 to $3000 \mathrm{~m}$ [5]. Sedimentation had started by the Early(?) to Middle Miocene with mainly lacustrine deposition [28, 32-35]. These lacustrine basin facies, especially Lower(?) to Middle Miocene units, provide the most important source rock potential [5]. These units are mainly composed of well-bedded and laminated bituminous shale (paper shale) intercalated with intervals of turbiditic sandstone and thinbedded sandstone-siltstone alternations [4, 5, 12, 28, 29, 34].

Outcrops of the Küçükkuyu Formation show that it is extensively developed in onshore areas. Facies and thickness variation of the formation in the buried areas is interpreted to be more widespread than in the outcrop areas. The Edremit Graben is one of the largest E-W trending grabens of western Anatolia. The graben is asymmetrical. It is about $80 \mathrm{~km}$ long and enlarges westward from about $5 \mathrm{~km}$ to more than $30 \mathrm{~km}$ [12]. The Edremit Graben fill in Edremit-1 well is about $2700 \mathrm{~m}$ thick according to seismic data. [3-5]. Volcanic content is significant in Edremit-1, Ayvalık-1, and Foça-1 in the northern basins of western Anatolia [5]. The Küçükkuyu Formation was not intersected in the Edremit-1 well up to $2700 \mathrm{~m}$. The formation is overlain by Upper Miocene and more recent volcanicvolcaniclastic rocks in the region and is partially hidden beneath the Upper Miocene unit. Because of this, the distribution of the Küçükkuyu Formation must be further investigated. Its depositional environment and relationship with the lacustrine sediments of western Anatolia should be examined. A question related to basin size that needs investigation is whether the Küçükkuyu Formation was deposited in a large lake (or interior sea) or in a small lacustrine basin with limited source rocks.

Source rock analysis of organic rich sediments of the formation on Biga Peninsula provided the following results:

(i) The samples generally have a TOC content of over $0.5 \mathrm{wt} \%$ with a mean of $1.69 \mathrm{wt} \%$, indicating that the formation is a good potential source rock. TOC values are different in Küçükkuyu and Kızılelma samples. While the Küçükkuyu samples have quite high TOC values (average $2.31 \mathrm{wt} \%$ ) which indicate good source rock characteristic, those of Kizılelma samples are considerably lower (average $0.79 \mathrm{wt} \%$ ), suggesting moderate source rock characteristic. HI values of Kizilelma samples are also very low (0 to $5 \mathrm{mg}$ $\mathrm{HC} / \mathrm{g} \mathrm{TOC})$. 
(ii) The OM of the samples is predominantly gas-prone Type III and to a lesser extent oil-gas prone Type II kerogen. CPI values support the idea that terrestrial OM is dominant. All the Kizılelma samples have very low HI values, therefore these samples have Type IV kerogen containing mainly reworked organic debris having limited gas potential.

(iii) The samples are predominantly early mature according to the measured Ro and $\mathrm{T}_{\max }$ values. CPI results indicate that the samples are not mature enough for hydrocarbon generation, although values could increase in the buried areas. According to PI data the Küçükkuyu Formation is not sufficiently mature to generate oil and gas in the Küçükkuyu area but is over mature in the Kizilelma area.

(iv) The Küçükkuyu Formation has a good source rock potential for hydrocarbon generation as supported by high values of TOC, HI and potential yield in the Küçükkuyu area. But the formation has no source rock potential in the Kizılelma area. The Kizılelma samples have $<1 \mathrm{wt} \%$ TOC values. Hydrocarbon yield and HI values are very low. Also, all samples in this area are overmature.

(v) $\mathrm{The} \mathrm{Pr} / \mathrm{Ph}$ values $(0.24-1.42)$ suggest that the samples were deposited in an anoxic-suboxic environment.

(vi) According to the geological and stratigraphic evolution, and TOC/TS values, the formation was deposited in a lacustrine freshwater environment.

\section{Acknowledgements}

The study was supported financially by the Çanakkale Onsekiz Mart University Scientific Research Foundation (ÇOMÜ-BAP, Project number: 2007/46). Analyses were carried out in the Organic Geochemistry Laboratory, Turkish Petroleum Corporation (TPAO).

\section{REFERENCES}

1. Saka, K. Geology and Hydrocarbon Possibility of Edremit Gulf and Surroundings of Neogene. Turkish Petroleum Corporation Research Group Technical Archive, unpublished technical report, 1979, Report No. 1341, 17 pp (in Turkish).

2. Siyako, M., Bürkan, K. A., Okay, A. I. Tertiary geology and hydrocarbon potential of the Biga and Gelibolu Peninsulas. Turkish Association of Petroleum Geologists Bulletin, 1989, 1, 183-199 (in Turkish with English abstract).

3. Kesgin, Y. Tertiary Geology and Sedimentology of the Northeastern Aegean Offshore and Nearshore Regions. PhD Thesis, Ankara University, 2001, 265 pp (in Turkish with English abstract).

4. Çiftçi, N. B., Temel, R. Ö., Terzioğlu, M. N. Neogene stratigraphy and hydrocarbon system of the region surrounding the Gulf of Edremit, NW Anatolia, 
Turkey. Turkish Association of Petroleum Geologists Bulletin, 2004, 16, 81104 (in Turkish with English abstract).

5. Çiftçi N. B., Temel, R. Ö., İztan, H. Hydrocarbon occurrences in western Anatolian (Aegean) graben basins, Turkey: is there a working petroleum system? Am. Assoc. Petr. B., 2010, 94(12), 1827-1857.

6. Bingöl, E. Contribution a l'Étude Geologique de la Partie Centrale et Sud-East du Massif de Kazdăg (Turquie). Thèse du doctorat, Université de Nancy, 1968, $189 \mathrm{pp}$.

7. Bingöl, E., Akyürek, B., Korkmazer, B. Geology of the Biga Peninsula and some characteristics of the Karakaya Formation. Proceedings of the 50th Anniversary of Turkish Republic Earth Sciences Congress, Mineral Research and Exploration Institute of Turkey Publications, 1975, 70-75 (in Turkish).

8. Okay, A. I., Siyako, M., Bürkan, K. A. Geology and tectonic evolution of the Biga Peninsula. Turkish Association of Petroleum Geologists Bulletin, 1990, 2, 83-121 (in Turkish with English abstract).

9. Duru, M., Pehlivan, Ş., Şentürk, Y., Yavaş, F., Kar, H. New Results on the lithostratigraphy of the Kazdağ Massif in northwest Turkey. Turk. J. Earth Sci., 2004, 13, 177-186.

10. Şengün, F., Çalık, A. Metamorphic features and correlation of the Çamlica metamorphics (Biga Peninsula, NW Turkey). Geological Bulletin of Turkey, 2007, 50, 1-16 (in Turkish with English abstract).

11. Ercan, T. Geological, archaeological and historical features of Biga and Gallipoli peninsulas with Gökçeada, Tenedos and Tavşan islands. Bulletin of the Mineral Research and Exploration, Earth Sciences and Culture Series, 1996, 1, 71 pp (in Turkish).

12. Yilmaz, Y., Karacik, Z. Geology of the northern side of the Gulf of Edremit and its tectonic significance for the development of the Aegean grabens. Geodin. Acta, 2001, 14(1-3), 31-43.

13. Beccaletto, L. Geology, Correlations and Geodynamic Evolution of the Biga Peninsula (NW Turkey). PhD Thesis, University of Lausanne, 2004, 146 pp.

14. İnci, U. The stratigraphy and organic properties of Demirci and Burhaniye bituminous shales. Bulletin of the Geological Congress of Turkey, 1984, 5, 27 40 (in Turkish with English abstract).

15. Tissot, B. P., Welte, D. H. Petroleum Formation and Occurrence. SpringerVerlag, Berlin, 1978.

16. Tissot, B. P., Welte, D. H. Petroleum Formation and Occurrence, Second revised and enlarged edition, Springer-Verlag, New York, 1984.

17. Vandenbroucke, M., Largeau, C. Kerogen origin, evolution and structure. Org. Geochem., 2007, 38, 719-833.

18. Peters, K. E., Cassa, M. R. Applied source rock geochemistry. In: The Petroleum System - From Source to Trap (Magoon, L. B., Dow, W. G., eds.), AAPG Memoir, 1994, 60, 93-120.

19. Peters, K. H., Moldowan, J. M. The Biomarker Guide. Interpreting Molecular Fossils in Petroleum and Ancient Sediments, Prentice Hall, Englewood Cliffs, NJ, 1993.

20. Peters, K. E., Walters, C. C., Moldowan, J. M. The Biomarker Guide: Biomarkers and Isotopes in the Environment and Human History, Cambridge University Press, Cambridge, UK, 2005, 1155 pp. 
21. Didyk, B. M., Simoneit, B. R. T., Brassell, S. C., Eglinton, G. Organic geochemical indicators of paleoenvironmental conditions of sedimentation. Nature, 1978, 272, 216-222.

22. Meyers, P. A. Preservation of elemental and isotopic source identification of sedimentary organic matter. Chem. Geol., 1994, 114(3-4), 289-302.

23. Leventhal, J. S. An interpretation of carbon and sulfur relationships in Black Sea sediments as indicator of environments of deposition. Geochim. Cosmochim. Ac., 1983, 47(1), 133-137.

24. Berner, R. A. Sedimentary pyrite formation: an update. Geochim. Cosmochim. Ac., 1984, 48(4), 605-615.

25. Berner, R. A., Raiswell, R. C/S method for distinguishing freshwater from marine sedimentary rocks. Geology, 1984, 12(6), 365-368.

26. Okay, A. I., Satır, M. Coeval plutonism and metamorphism in a latest Oligocene metamorphic core complex in northwest Turkey. Geolog. Mag., 2000, 137(5), 495-516.

27. Proedrou, P., Papaconstantinou, C. M. Prinos Basin - A model for oil exploration. Bulletin of the Geological Society of Greece, 2004, 36, 327-333.

28. Çiftçi, N. B., Bozkurt, E. Evolution of the Miocene sedimentary fill of the Gediz graben, SW Turkey. Sediment. Geol., 2009, 216(3-4), 49-79.

29. Yılmaz, Y, Genç, Ş. C., Gürer, Ö. F., Bozcu, M., Yılmaz, K., Karacık, Z., Altunkaynak, Ş., Elmas, A. When did the western Anatolian grabens begin to develop? In: Tectonics and Magmatism in Turkey and Surrounding Area (Bozkurt, E, Winchester, J. A., Piper, J. D. A., eds.), Geological Society of London Special Publication, 2000, 173, 353-384.

30. Yazman, M. K., Çopur, S., Özdemir, İ., İztan, Y. H., Sayılı, A., Batı, Z. Geology, Oil Possibilities of Büyük Menderes Graben (Germencik from Denizli) and Nazilli-1 Exploration Well, TPAO (Turkish Petroleum Corporation) Technical Report, 2004, Report No. 4546, 71 pp (in Turkish).

31. Gürer, O. F., Bozcu, M., Yılmaz, K., Yılmaz, Y. Neogene basin development around Söke-Kuşadası (western Anatolia) and its bearing on tectonic development of the Aegean region. Geodin. Acta, 2001, 14(1-3), 57-69.

32. İztan, H., Yazman, M. Geology and hydrocarbon potential of the Alaşehir (Manisa) area, western Turkey. In: Proceedings of International Earth Sciences Congress, Aegean Region (Savaşçın, M. Y., Eronat, A. H., eds.), 1990, 327 333.

33. Seyitoğlu, G., Scott, B. C. The age of the Büyük Menderes graben (west Turkey) and its tectonic implications. Geol. Mag., 1992, 129(2), 239-242.

34. Ediger, V. Ş., Batı, Z., Yazman, M. Paleopalynology of possible hydrocarbon source rocks of the Alaşehir-Turgutlu area in the Gediz graben (western Anatolia). Turkish Association of Petroleum Geologists Bulletin, 1996, 8, 94112 (in Turkish with English abstract).

35. Purvis, M., Robertson, A. Miocene sedimentary evolution of the NE-SWtrending Selendi and Gördes basins, W Turkey: implications for extensional processes. Sediment. Geol., 2005, 174(1-2), 31-62.

36. Okay, A. I., Satır, M. Upper Cretaceous eclogite-facies metamorphic rocks from the Biga Peninsula, Northwest Turkey. Turk. J. Earth Sci., 2000, 9, 4756.

37. Şengün, F., Yiğitbaş, E., Tunç, İ. O. Geology and tectonic emplacement of eclogite and blueschists, Biga peninsula, northwest Turkey, Turk. J. Earth Sci., 2011, 20, 273-285. 
38. Okay, A. I., Siyako, M., Bürkan, K. A. Geology and Tectonic Evolution of the Biga Peninsula. TPAO (Turkish Petroleum Corporation) technical report, 1990. Report No. 2746, 107 pp (in Turkish).

39. Espitalie, J., Deroo, G., Marquis, F. La pyrolyse Rock-Eval et ses applications. Rev. I. Fr. Petrol., 1985, 40(5), 563-579; 40(6), 755-784.

Presented by A. Soesoo

Received September 9, 2014 